\title{
A New Definition of Religious Ritual Qing LAN
}

School of Social Administration, Kunming University, Puxin Road, Kunming, Yunnan, China, 650214 Email: adbag@sina.com

Keywords: Ritual, Religion, Belief Theory

\begin{abstract}
In social science, ritual is a concept often used, especially in religion study. But we have not a successful definition of ritual yet. This means we can not distinguish it from normal behavior. Many anthropologists have endeavored to define ritual, while they all failed because they lacked an adequate theory of social action. Belief theory is a new general theory of social science. Basing on it, we attempt to make religion ritual clear.
\end{abstract}

\section{Introduction}

In Predicaments of rite of passage, my paper accepted by ESHD 2018, I have pointed the difficulties of the rite of passage as a concept. I have argued the best choice for us is never using it again. Now I will change my attention to ritual which is more important than the rite of passage. Ritual facing the similar problem like the rite of passage, we do not know the usage limit of it.

1977, a paper with radical view of ritual has been published in a symposium. In this paper, famous English anthropologist Goody examined the definitions of ritual by Bocock, Turner and Tambiah. He concluded the use of rituals should be abandoned as an analytical concept [1]. But very strange, Goody did not discuss his own definition [2] full with same problems like theirs.

Facing Goody's challenge, most researchers think it is impossible to give a precise definition to the ritual. A wide accepted way has been given by Bell in 1990s. She suggested human behavior can not be cut into ritual and non-ritual. Human behavior is a continuous spectrum from ritual to ritual-like. [3] But if we go along this way, it equals to the Goody's. According to epistemology, enlarging the extension of a concept limitlessly means canceling the concept. Like discussed in Predicaments of rite of passage, you can call having a meal in the restaurant a ritual nor not.

\section{Ritual in the Belief Theory}

As a kind of social behavior, the ritual follows the law of behavior. Once we have a general theory of social behavior, it will be not so difficult to understanding rituals. The belief theory is just the one.

The belief theory is born at 2008. [4] This is the first general theory in the history of social science. The belief concept in this theory is the judgement of the proposition, means we think the proposition is right or not. "I think it will rain" is a belief; "I don't think it will rain" is also a belief. The theory puts the belief as the cause of human behavior. Which kind of belief we have, which kind of behavior follows. In belief theory, belief has a state of entity in the sense of ontology. Because all belief is ideas, vis-a-vis nature science, the social science must take the ontology of idea.

All human beliefs are the representation of the world. We face the world and form our thinking, whether right or wrong, these judgement will become the propositions. The propositions we think right will guide our behavior. There is the cause relationship between the belief and behavior. We think it right and do it.

The belief theory is the one based on human believes. Belief is the judgement of human being, it comes from human being's represent of the world, so belief theory is just thinking about what human being think. The result in real world does not have basic state. 
Obviously people carry on a ritual with some aims. We want make some change through the ritual. In the view of belief theory, we carry on a ritual because we think the ritual can change something. We do the ritual make children into adults. We do the ritual guide the decedent to the place of ancestor. We do the ritual to speed some process or slow it. If we belief some change, like old and dead, is a nature process, we maybe want to stop the change through the ritual.

So in the belief theory, the ritual is the method to make some change. The point is also right to the ordinary behavior. If we want distinguish ritual from ordinary behavior, we must tell the difference between the ritual and ordinary behavior on some facet, aims or forms of action.

\section{A New Definition of Religious Ritual}

We now arrive the conclusion that all actions, including rituals, aim to change something. If we want to define ritual, it must include the difference between ritual and nonritural. It is a hard work of classification of action, for human behavior is so complex. Nearly every textbook of religion will have a chapter of ritual. Faith and ritual are thought usually two parts of religion. Religion behavior is comprised of rituals mostly. So before defining ritual, I want to lighten our mission and define religious ritual firstly. On this step, we might discuss the general definition of ritual in future.

The stumbling block on this way is religion. There are few concepts in social science with clear and reliable definition before the belief theory advanced. Fortunately, Cai has given us a definition of religion recently. [5] Mental existence (ME) has been classified into without material support (ME1) and with physical support (ME2). There are two kinds of ME1, spirit (ME1a) and demon (ME1b); two kinds of ME2, human (ME2a) and medium (ME2b). Cai defined religion an association between two categories of ME.

As we has discussed above, ritual must be some action involving change. Religious ritual can be defined the action which intends to change the relations between the ME1 and ME2: Religious rituals are acts aiming to change the relationship between the ME1 and ME2.

Actually, there are ten different kinds of relation among ME.

Table 1. The relations among MEs.

\begin{tabular}{|l|l|l|l|l|}
\hline ME & $1 a$ & $1 b$ & $2 a$ & $2 b$ \\
\hline $1 a$ & $1 a 1 a$ & $1 a 1 b$ & $1 a 2 a$ & $1 a 2 b$ \\
\hline $1 b$ & $1 b 1 a=1 a 1 b$ & $1 b 1 b$ & $1 b 2 a$ & $1 b 2 b$ \\
\hline $2 a$ & $2 a 1 a=1 a 2 a$ & $2 a 1 b=1 b 2 a$ & $2 a 2 a$ & $2 a 2 b$ \\
\hline $2 b$ & $2 b 1 a=1 a 2 b$ & $2 b 1 b=1 b 2 b$ & $2 b 2 a=2 a 2 b$ & $2 b 2 b$ \\
\hline
\end{tabular}

In table 1, we can see there are relations among ME1 and ME2, why I do not include the relations in the definition? First, the relations among ME2, including 2a2a, 2a2b, 2b2b, are obviously the social relation out religion. Second, although the relations among ME1 (1a1a, 1a1b, 1b1b) are religious, people will no perform the ritual only aiming to change the relations but not involving the relation between ME1 and ME2. The ultimate wish is always the change of ME2.

What left in the end is four effective relations:

Table 2. Four effective relations between MEs.

\begin{tabular}{|l|l|l|}
\hline ME & 2a & 2b \\
\hline $1 \mathrm{a}$ & $1 \mathrm{a} 2 \mathrm{a}$ & $1 \mathrm{a} 2 \mathrm{~b}$ \\
\hline $1 \mathrm{~b}$ & $1 \mathrm{~b} 2 \mathrm{a}$ & $1 \mathrm{~b} 2 \mathrm{~b}$ \\
\hline
\end{tabular}


Now we have four kinds of religious ritual according the relations the ritual want to change. In addition, more than one kind of relations will be changed in one ritual, but the ultimate target is often just one.

The 1a2a is the relation between spirit and human. This kind of religious ritual including ancestor sacrifice, praying dragon god for rain in China, pilgrimage etc.

The $1 \mathrm{a} 2 \mathrm{~b}$ is the relation between spirit and medium. When human can not contact gods, we need a medium. The medium is a bridge connecting this world and another. This kind of ritual is common in religion. We beg a priest to deliver our wish to gods. Shamans tell us the gods' attitudes about our actions.

The 1b2a is the relation between demon and human. Demons are harm to human. Some rituals expel them from living beings, some rituals call they to hit enemies.

The $1 \mathrm{~b} 2 \mathrm{~b}$ is the relation between demon and medium. For normal person, demon is also unperceptible also. Sometime we want to know what demons want, and then medium can ask they in certain rituals.

When people carry on a ritual, in general, we can find four kinds of person. First, the people who want do the ritual. Second, the people who the ritual will change. Third, the specialist who perform the ritual. Forth, the onlooker. Sometimes, parts of these four kinds people will be coincide. In our definition, the change is depended on the belief of at least one of the first, second, and third. The attitude of onlooker is not been included.

In this definition and classification, nearly all religious behavior is included. It need to further study whether there is some religious behavior is not ritual.

\section{Conclusion}

Our primary duty has been accomplished already. We get a definition and a classification of religious ritual. This new definition is not opaques again, it give us a so clear judging standard. In this definition the relation of the method and aim is not included. I don't care the result of the religious ritual in real world. On the contrary, I think this way is not only useless but also misleading.

Furthermore, the classification of relations of ME is an useful frame in ritual analysis. It tell us what kinds of relations should be the important point and not be lost. Four kinds of the relation in table 2 are all we must be looking for in religious ritual study. Then we can follow the religious specialists in the ritual easily, asking them the effect of every act.

The most important is we no longer think “objective” facts are useful in ritual study. Our burden will light. It will simplify our research. We will easily find new and interesting result. In the past, we have been trapped in the debate of the effect of ritual. It demand us to evaluate the real result of ritual, it's so difficult for it is usually a question of nature science and irrelevant to social science. The web of meaning is weaved ideas of human being, the duty of social science is just pursuing these ideas.

In this paper, we have connected religious faith and ritual perfectly. We know the ritual is based on the faith, the faith guides the ritual. So traditional dichotomy study method, one is faith, the other is ritual, has lost its legality.

\section{Acknowledgement}

This research was financially supported by the Research Foundation for Introduction Talent of Kunming University. 


\section{References}

[1] J. Goody, Against 'Ritual', in: S. Moore and B. Myerhoff (Eds.), Secular Ritual, van Gorcum, Amsterdam, 1977, pp.25-35.

[2] J. Goody, Religion and Ritual: The Definition Problem, the British J. of Sociology. 12 (1961) 142-164.

[3] C. Bell, Ritual: Perspectives and Dimensions, Oxford University Press, New York, 1997, part II.

[4] H. Cai, L’hommo Penseé par L’hommo, Presses Universitaires de France, Paris.

[5] H. Cai, Esprit Humain Démon (et leur médium): La 'religion’ en tant que Terme Technique demeure-t-elle Utile?, http://jominken.kanagawa-u.ac.jp/triangle/mqgqct0000000nqo-att/HUA_C.pdf, 2013. 